\title{
PERBEDAAN HASIL BELAJAR IPA BIOLOGI MENGGUNAKAN MODEL PEMBELAJARAN KOOPERATIF TIPE NUMBERED HEADS TOGETHER (NHT) DENGAN THINK PAIR SHARE (TPS) PADA SISWA KELAS VIII SMPN 13 MATARAM TAHUN AJARAN 2015/2016
}

\author{
Miftahul Hasanah'1, Agil Al Idrus ${ }^{2}$, dan I Gde Mertha ${ }^{3}$ \\ ${ }_{1}^{1}$ Mahasiswa Pendidikan Biologi FKIP Universitas Mataram \\ 2, 32Dosen Pendidikan Biologi FKIP Universitas Mataram
}

\begin{abstract}
Abstrak
Tujuan penelitian ini adalah untuk mengetahui perbedaan hasil belajar IPA Biologi yang belajar dengan model pembelajaran kooperatif tipe NHT dengan TPS pada siswa kelas VIII di SMPN 13 Mataram Tahun Ajaran 2015/2016. Jenis penelitian ini termasuk eksperimen. Perolehan data menggunakan instrumen tes untuk melihat hasil belajar aspek kognitif dan lembar observasi untuk mengetahui aktifitas siswa dan keterlaksanaan RPP. Uji hipotesis menggunakan uji t polled varian karena data terdistribusi normal dan bersifat homogen. Hasil Post-test 1 thitung $=4,01$ dan hasil Posttest $2 t_{\text {hitung }}=4,58$ dengan harga $t_{\text {tabel }}=1,67$. Hasil uji hipotesis untuk kedua model di kelas eksperimen 1 adalah $t_{\text {hitung }}=-5,87$ dan kelas eksperimen $2 t_{\text {hitung }}=-5,78$ dengan harga $t_{\text {tabel }}=1,67$. Hasil uji hipotesis yang diperoleh menyatakan Ho ditolak dan $\mathrm{Ha}$ diterima sehingga secara statistik terdapat perbedaan yang signifikan $(\alpha=5 \%)$ terhadap hasil belajar IPA Biologi siswa yang belajar menggunakan model NHT dengan TPS.
\end{abstract}

Kata Kunci: Pembelajaran Kooperatif. Think Pair Share, Numbered Heads Together, Hasil Belajar 


\section{PENDAHULUAN}

Belajar merupakan suatu proses yang dialami oleh setiap orang, baik laki-laki maupun perempuan, anak-anak maupun dewasa atau bahkan tua, belajar dialami sepanjang masa karena belajar tidak mengenal batasan usia. Belajar juga tidak mengenal batasan baik dari segi waktu, tempat dan subjek belajar. Melalui proses belajar seseorang diharapkan mengalami suatu perubahan dari tidak bisa menjadi bisa. Belajar meliputi adanya perkembangan pengetahuan, keterampilan, sikap dan tingkah laku pada peserta didik yang terjadi sebagai akibat dari kegiatan mengobservasi, mendengar, mencontoh dan mempraktekkan suatu kegiatan.

Teori pokok belajar ada 3 yakni teori behavioristik yang menekankan bahwa belajar merupakan hubungan antara stimulus yang diberikan dengan respon terhadap stimulus. Prinsip dalam pembelajaran meliputi seseorang dikatakan belajar apabila ada perubahan tingkah laku, hal yang terpenting dalam belajar adalah adanya stimulus dan respon karena keduanya mudah diamati, hal apa saja yang menguatkan dalam belajar termasuk hal terpenting. Teori selanjutnya yakni teori kognitif yang menyatakan belajar disesuaikan dengan tahap perkembangan kognitif peserta didik. Salah satu ahli yang menganut teori ini ialah Peaget, ia mengemukakan aspek perkembangan kognitif seseorang terdapat tahap sensory motor, tahap preoperasional, tahap concrete operational, tahap formal operational. Teori ketiga yakni teori konstruktivisme, teori ini menyatakan bahwa pembelajaran melibatkan peserta didik untuk membangun sendiri pengetahuannya secara aktif dengan menggunakan pengetahuan yang telah dimiliki sebelumnya.

Hasil belajar diperoleh dari proses belajar. Hasil belajar digolongkan ke dalam tiga aspek yaitu hasil belajar aspek kognitif yang berkaitan dengan pengetahuan, aspek afektif yang berkaitan dengan sikap dan aspek psikomotorik yang berkaitan dengan keterampilan. Proses belajar yang dilaksanakan dengan baik akan memperoleh hasil yang baik, sebaliknya proses belajar yang kurang baik akan memperoleh hasil yang kurang baik juga. Setiap orang mengharapkan hasil belajar yang baik. Oleh karena itu

212 BIOTA: Jurnal Tadris IPA Biologi FITK IAIN Mataram 
banyak cara yang digunakan untuk mencapai hasil sesuai dengan yang diharapkan. Seorang guru tentunya akan menggunakan variasi dalam mengajar dengan tujuan agar peserta didik tidak mudah bosan sehingga materi pelajaran dapat dipahami yang pada akhirnya akan diperoleh hasil sesuai dengan yang diharapkan. Salah satu variasi mengajar yang dapat dilakukan adalah dengan variasi model pembelajaran. Proses pembelajaran yang dilaksanakan hendaknya mampu menciptakan pembelajaran aktif, efektif dan menyenangkan sebagaimana yang diharapkan pada kurikulum 2006 (KTSP). Model pembelajaran yang dapat menciptakan suasana belajar yang aktif, kreatif dan menyenangkan seperti model pembelajaran kooperatif. Pembelajaran kooperatif adalah konsep yang luas meliputi semua jenis kerja kelompok termasuk bentuk yang dipimpin oleh guru. Secara umum pembelajaran kooperatif dianggap lebih diarahkan oleh guru dimana guru menetapkan tugas dan menyediakan informasi yang dapat membantu peserta didik dalam menyelesaikan masalah.

Kurikulum tahun 2006 (KTSP) menginginkan bahwa peserta didik berperan aktif dalam proses belajar mengajar sehingga hasil belajar meningkat. Kurikulum 2006 (KTSP) adalah kelengkapan dari Kurikulum 2004 (KBK), kemudian dilengkapi oleh Kurikulum 2013. Kurikulum 2006 dalam proses pembelajaran melaksanakan langkah Eksplorasi, Elaborasi dan Konfirmasi. Penilaian lebih dominan pada aspek kognitif tanpa melupakan penilaian aspek afektif dan psikomotorik, sedangkan pada kurikulum 2013 dalam pembelajaran melaksanakan langkah Mengamati, Menanya, Mencoba, Mengasosiasi dan Mengkomunikasikan. Penilaian aspek kognitif, afektif dan psikomotor dilakukan secara langsung saat proses pembelajaran. Kurikulum 2013 adalah kurikulum berbasis kompetensi yang pernah digagas dalam Rintisan Kurikulum Berbasis Kompetensi (KBK) 2004, tapi belum terselesaikan karena desakan untuk segera mengimplementasikan Kurikulum Tingkat Satuan Pendidikan (KTSP) 2006. Rumusannya berdasarkan pada sudut pandang yang berbeda dengan kurikulum berbasis materi, sehingga sangat dimungkinkan terjadi perbedaan persepsi 
tentang bagaimana kurikulum seharusnya dirancang. Agar peserta didik dapat berperan aktif dalam proses belajar mengajar maka diperlukan model belajar seperti model pembelajaran kooperatif yang membutuhkan kerjasama antar peserta didik. Pembelajaran dengan model kooperatif dapat memberikan kesempatan bagi peserta didik untuk mengemukakan pendapatnya masing-masing tanpa harus ada rasa takut.

Model pembelajaran kooperatif memiliki banyak tipe seperti Jigsaw, Team Game Tournament (TGT), STAD, Make and Match, Numbered Heads Together (NHT) dan Think Par Share (TPS). Model pembelajaran Numbered Heads Together (NHT) dan Think Par Share (TPS) termasuk ke dalam strategi struktural. Sintaks pembelajaran pada Numbered Heads Together (NHT) dengan Think Pair Share (TPS) memberikan kesempatan kepada peserta didik untuk menggali sendiri informasi yang ada dan telah diketahui sebelum melakukan diskusi dan tukar pikiran dengan temannya. Hal tersebut diharapkan dapat meningkatkan keaktifan dan motivasi peserta didik yang akhirnya berpengaruh juga terhadap hasil belajar aspek kognitif.

Model pembelajaran Numbered Heads Together dan Think Pair Share memiliki keunggulan masing-masing. Numbered Heads Together memiliki keunggulan adanya interaksi antar peserta didik dalam proses belajar, peserta didik yang pandai dapat membantu peserta didik yang kurang pandai, adanya saling melengkapi antar peserta didik. Think Pair Share membantu peserta didik meningkatkan kemampuan mengingat informasi. Kondisi peserta didik, sarana dan prasarana yang ada di SMPN 13 Mataram mendukung dilaksanakannya pembelajaran dengan model kooperatif tipe Numbered Heads Together dan Think Pair Share.

Menurut hasil penelitian Permana [7] menyatakan bahwa pembelajaran kooperatif tipe berpikir-berpasangan-berbagi atau TPS ini lebih memotivasi peserta didik dalam mengikuti pembelajaran karena tahapan-tahapan dalam pembelajaran kooperatif tipe Think Pair Share ini memberikan keuntungan bagi peserta didik. Tahapan Think menggalakkan kegiatan berpikir peserta didik sehingga kualitas jawaban meningkat. Tahap Pair

214 BIOTA: Jurnal Tadris IPA Biologi FITK IAIN Mataram 
efektif dalam memudahkan peserta didik memahami materi dan memecahkan permasalahan dan dengan cara ini peserta didik mampu bekerja sama, saling membutuhkan dan bergantung satu sama lain dalam kelompok yang kecil. Tahap Share dilakukan secara berpasangan sehingga terlihat peserta didik antusias dan ikut berpartisipasi, memberikan tanggapan dan mengajukan pertanyaan.

Motivasi merupakan dorongan yang muncul dari dalam diri untuk bertingkah laku. Dorongan ini umumnya diarahkan untuk mencapai suatu tujuan. Motivasi dapat memberikan semangat untuk berperilaku dan memberikan arah dalam belajar. Seseorang akan melakukan sesuatu bagaimanapun berat dan sulitnya apabila memiliki motivasi yang tinggi baik dari dalam maupun luar diri

Hasil penelitan Muamar dan Amelia menyatakan bahwa hasil belajar peserta didik pada materi hidrosfer terdapat perbedaan setelah menggunakan model pembelajaran kooperatif tipe Think Pair Share (TPS) dan Numbered Heads Together (NHT). Hasil belajar setelah diberikan tes menunjukkan adanya peningkatan dilihat dari perbandingan nilai pre test dan post test. Hasil belajar menggunakan Think Pair Share (TPS) dan Numbered Heads Together (NHT) sama-sama meningkat akan tetapi nilai rata-rata kelas yang menggunakan model kooperatif tipe Numbered Heads Together (NHT) lebih tinggi daripada kelas yang menggunakan model kooperatif tipe Think Pair Share (TPS).

Berdasarkan latar belakang tersebut peneliti ingin melakukan penelitian yang berjudul "Perbedaan Hasil Belajar IPA Biologi Menggunakan Model Pembelajaran Kooperatif Tipe Numbered Heads Together (NHT) dengan Think Pair Share (TPS) pada Siswa Kelas VIII SMP Negeri 13 Mataram Tahun Ajaran 2015/2016". 


\section{METODE PENELITIAN}

Jenis penelitian ini adalah quasi eksperimen. Penelitian ini dilakukan di SMPN 13 Mataram pada siswa kelas VIII semester ganjil tahun ajaran 2015/2016. Populasi dari penelitian ini adalah seluruh kelas VIII yang terdiri dari delapan kelas, teknik sampel penelitian ini menggunakan simple random sampling, sehingga diperoleh kelas VIII G sebagai kelas eksperimen 1 dan kelas VIII H sebagai kelas eksperimen 2 yang diberikan perlakuan model pembelajaran kooperatif tipe Numbered Heads Together (NHT) dan Think Pair Share (TPS). Materi yang disampaikan mengenai pertumbuhan dan perkembangan pada makhluk hidup.

Variabel bebas dalam penelitian ini adalah penggunaan model pembelajaran kooperatif tipe Numbered Heads Together (NHT) dan Think Pair Share (TPS) sedangkan variabel terikatnya adalah hasil belajar IPA Biologi siswa. Instrumen yang digunakan untuk mengukur hasil belajar aspek kognitif dengan menggunakan tes berupa pilihan ganda yang sudah valid dan reliabel sebanyak 38 soal. Analisis uji hipotesis menggunakan uji-t dengan bantuan program Microsoft Excel.

\section{HASIL DAN PEMBAHASAN}

Sebelum diberikan perlakuan menggunakan model pembelajaran Numbered Heads Together (NHT) dan Think Pair Share (TPS) terlebih dahulu dilakukan pre test bertujuan untuk mengetahui pengetahuan awal siswa tentang materi pertumbuhan dan perkembangan. Nilai rata-tata yang diperoleh kelas eksperimen 1 adalah 35,61 dan kelas eksperimen 2 memperoleh nilai rata-rata 45,30. Selanjutnya, setelah diberikan pre test kedua kelas belajar dengan menggunakan diberikan perlakuan model pembelajaran Numbered Heads Together (NHT) dan Think Pair Share (TPS). Kelas eksperimen satu diberi perlakuan menggunakan model NHT terlebih dahulu dan kelas eksperimen menggunakan model TPS. Setelah perlakuan diberikan, kedua kelas melakukan post test 1 dan hasilnya kelas eksperimen satu memperoleh nilai rata-rata sebesar 53,07 dan eksperimen 2 memperoleh nilai rata-rata 44,20. Perlakuan

216 BIOTA: Jurnal Tadris IPA Biologi FITK IAIN Mataram 
berikutnya, kelas eksperimen 1 menggunakan model TPS dan kelas eksperimen 2 menggunakan model NHT. setelah diberikan perlakuan, kedua kelas melakukan post tes 2 dan hasilnya menunjukkan kelas eksperimen 1 memperoleh nilai rata-rata 66,77 dan kelas eksperimen 2 memperoleh nilai rata-rata sebesar 56,48. Perolehan nilai pre test dan post test kedua kelas dapat dilihat pada Gambar 1.

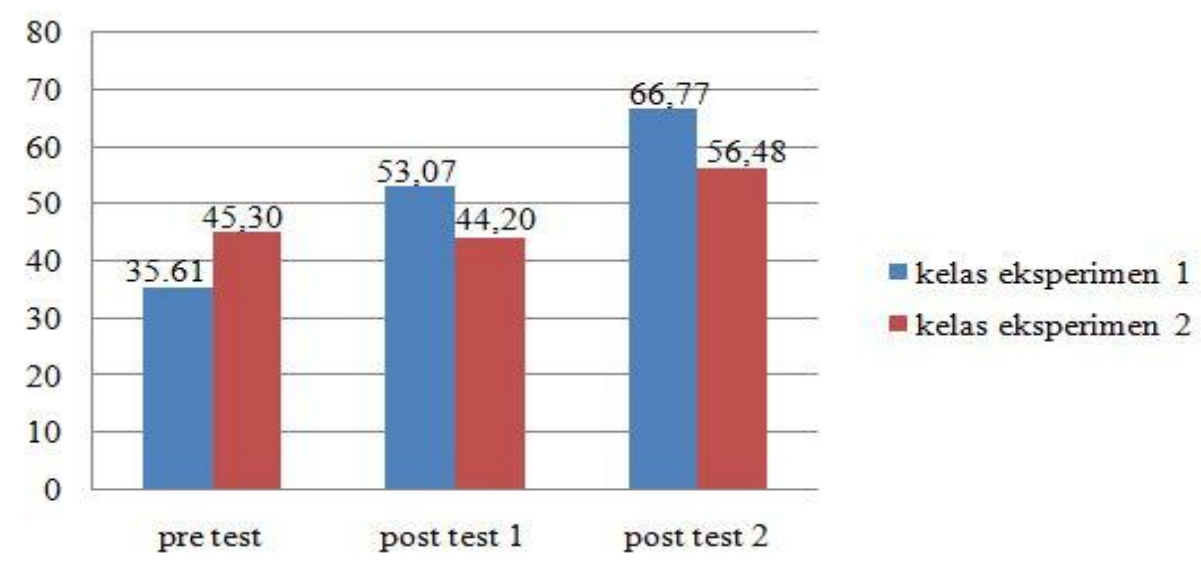

Gambar 1

Nilai pre test dan post test kelas eksperimen 1 dan eksperimen 2

Berdasarkan analisis uji perbedaan hasil belajar aspek kognitif pada post-test 1 menggunakan rumus t-Test pada program Microsoft Excel 2007, diketahui harga thitung $=4,01$ dengan derajat bebas 77 dan $\alpha=5 \%$ dan harga tabel $=1,67$. Berdasarkan hasil tersebut, diketahui thitung lebih besar daripada tabel $(4,01>1,67)$, sehingga Ho ditolak dan Ha diterima. Dengan demikian terbukti secara statistik bahwa terdapat perbedaan hasil belajar aspek kognitif antara siswa yang diberikan pembelajaran dengan model pembelajaran kooperatif tipe NHT dengan TPS. Hasil analisis uji hipotesis untuk post-test 1 kelas eksperimen 1 dan eksperimen 2 dapat dilihat pada Tabel 1. 
Tabel 1

Hasil Uji Hipotesis Data Post-test 1 Kelas Eksperimen 1 dan Eksperimen 2

\begin{tabular}{|c|c|c|}
\hline Statistik & Kelas eksperimen 1 & Kelas eksperimen 2 \\
\hline $\begin{array}{l}\text { Jumlah sampel } \\
\text { Rata-rata } \\
\text { Varians }\left(\mathrm{S}^{2}\right) \\
\text { thitung } \\
\text { t }_{\text {tabel }}\end{array}$ & $\begin{array}{l}39 \\
53,07 \\
117,17 \\
4,001 \\
1,67\end{array}$ & $\begin{array}{l}40 \\
44,20 \\
76,38 \\
t_{\text {hitung }}>\mathrm{t}_{\text {tabel }} \\
\mathrm{H}_{0} \text { ditolak, } \mathrm{H}_{\mathrm{a}} \\
\text { diterima } \\
\end{array}$ \\
\hline $\begin{array}{l}\text { Jumlah sampel } \\
\text { Rata-rata } \\
\text { Varians }\left(\mathrm{S}^{2}\right) \\
\text { thitung }_{\text {tabel }}\end{array}$ & $\begin{array}{l}39 \\
53,07 \\
117,17 \\
4,001 \\
1,67\end{array}$ & $\begin{array}{l}40 \\
44,20 \\
76,38 \\
t_{\text {hitung }}>\mathrm{t}_{\text {tabel }} \\
\mathrm{H}_{0} \text { ditolak, } \mathrm{H}_{\mathrm{a}} \\
\text { diterima } \\
\end{array}$ \\
\hline
\end{tabular}

Data post test 1 menunjukkan hasil yang lebih tinggi pada kelas yang nmenggunakan model pembelajaran NHT. Hasil penelitian ini sejalan dengan hasil penelitian Muzalifah [10] bahwa terdapat perbedaan hasil belajar kimia siswa antara yang menggunakan model pembelajaran kooperatif tipe NHT dengan TPS. Hasil belajar yang menggunakan model NHT lebih tinggi dibandingkan dengan hasil belajar siswa yang menggunakan model TPS. Hal ini dikarenakan model pembelajaran tipe NHT memberikan kesempatan kepada siswa untuk saling berbagi ide dan mempertimbangkan jawaban. Hasil penelitian ini juga didukung oleh hasil penelitian yang dilakukan Setiawan dkk [11] menyatakan bahwa hasil belajar aspek kognitif pada siswa kelas X materi kimia lebih tinggi menggunakan model NHT dibandingkan dengan menggunakan model TPS. Hal ini karena penggunaan model NHT memberikan kesempatan kepada siswa untuk bertukar pikiran, semakin banyak anggota dalam kelompok maka semakin banyak ide-ide yang diperoleh. Pelaksanaan model TPS hanya melibatkan dua orang dalam satu kelompok, jumlah

218 BIOTA: Jurnal Tadris IPA Biologi FITK IAIN Mataram 
anggota diskusi lebih sedikit dibandingkan dengan model NHT. Jumlah anggota kelompok yang sedikit menyebabkan jumlah kelompok semakin banyak dan tidak semua kelompok mendapat giliran untuk presentasi. Berbeda dengan model NHT, setiap anggota harus siap dengan apa yang akan ditanyakan oleh guru, umumnya kesempatan presentasi hasil kerja untuk setiap kelompok sama. Hasil tersebut juga didukung hasil penelitian yang dilakukan oleh Murti dkk [12] tentang studi komparasi model pembelajaran NHT dan TPS, hasilnya menunjukkan bahwa kelas yang menggunakan model pembelajaran NHT memperoleh nilai rata-rata yang lebih tinggi dibandingkan dengan kelas yang menggunakan model TPS. Hal ini karena pembelajaran dengan model NHT memberikan peluang untuk lebih banyak ide yang diperoleh dan dapat mempertimbangkan jawaban, sedangkan pada model TPS ide yang diperoleh sedikit, sulit untuk mempertimbangkan jawaban.

Penelitian lain yang mendukung hasil penelitian ini seperti yang dilakukan oleh Setyaningsih dkk [13] bahwa model pembelajaran NHT dan TPS memiliki pengaruh terhadap hasil belajar siswa pada materi koloid. Model pembelajaran NHT memperoleh hasil yang lebih baik dibandingkan dengan TPS. Hal serupa juga diperoleh Rahmawati [14] yang menyatakan bahwa model pembelajaran kooperatif tipe NHT dan TPS mempengaruhi hasil belajar siswa, akan tetapi hasil belajar yang menggunakan model NHT lebih baik dibandingkan dengan model pembelajaran TPS. Hal ini dikarenakan pada model NHT siswa lebih difokuskan untuk mencari, mengolah informasi dan melaporkan melalui kegiatan presentasi. Siswa terlibat lebih aktif karena pemberian nomor pada masing-masing menyebabkan siswa lebih mempersiapkan diri untuk presentasi.

Berdasarkan analisis uji perbedaan hasil belajar aspek kognitif pada post-test 2 menggunakan rumus $t$-Test pada program Microsoft Excel 2007, diketahui harga thitung $=4,58$ dengan derajat bebas 77 dan $\alpha=5 \%$ sehingga harga tabel $=1,67$. Berdasarkan hasil tersebut, diketahui thitung lebih besar daripada $t_{\text {tabel }}(4,58>1,67)$, sehingga Ho ditolak dan Ha diterima. Dengan demikian terbukti secara statistik bahwa terdapat perbedaan hasil 
belajar aspek kognitif antara siswa yang diberikan pembelajaran dengan model pembelajaran kooperatif tipe NHT dengan TPS. Hasil analisis uji hipotesis untuk post-test 2 kelas eksperimen 1 dan eksperimen 2 dapat dilihat pada Tabel 2.

\section{Tabel 2}

Hasil Uji Hipotesis Data Post-test 2 Kelas Eksperimen 1 dan Eksperimen 2

\begin{tabular}{|c|c|c|}
\hline Statistik & Kelas eksperimen 1 & Kelas eksperimen 2 \\
\hline $\begin{array}{l}\text { Jumlah sampel } \\
\text { Rata-rata } \\
\text { Varians }\left(S^{2}\right) \\
\text { thitung } \\
\text { ttabel }\end{array}$ & $\begin{array}{l}39 \\
66,77 \\
95,41 \\
4,58 \\
1,67\end{array}$ & $\begin{array}{l}40 \\
56,48 \\
103,92 \\
t_{\text {hitung }}>\mathrm{t}_{\text {tabel }} \\
\mathrm{H}_{0} \text { ditolak, } \\
\text { diterima }\end{array}$ \\
\hline $\begin{array}{l}\text { Jumlah sampel } \\
\text { Rata-rata } \\
\text { Varians }\left(\mathrm{S}^{2}\right) \\
\text { thitung } \\
\text { ttabel }\end{array}$ & $\begin{array}{l}39 \\
66,77 \\
95,41 \\
4,58 \\
1,67\end{array}$ & $\begin{array}{l}40 \\
56,48 \\
103,92 \\
t_{\text {titung }}>\mathrm{t}_{\text {tabel }} \\
\mathrm{H}_{0} \text { ditolak, } \mathrm{H}_{\mathrm{a}} \\
\text { diterima }\end{array}$ \\
\hline
\end{tabular}

Data hasil post test 2 secara statistik menunjukkan terdapat perbedaan hasil belajar, nilai rata-rata lebih tinggi ditunjukkan pada perlakuan menggunakan model TPS, hal ini karena dalam prosesnya siswa hanya berdiskusi secara berpasangan sehingga siswa lebih serius dan fokus. Hasil penelitian ini didukung oleh penelitian Muamar dan Amelia [15], hasilnya menunjukkan bahwa terdapat perbedaan hasil belajar siswa menggunakan model pembelajaran kooperatif tipe Think Pair Share dengan Numbered Heads Together pada materi hidrosfer. Hasil belajar menggunakan model Think Pair Share lebih baik dibandingkan dengan hasil belajar menggunakan model Numbered Heads Together. Hasil penelitian ini sejalan dengan hasil penelitian Aisyah dkk [16] 
menyatakan bahwa model pembelajaran TPS memberikan hasil belajar aspek kognitif yang lebih baik jika dibandingkan dengan model NHT. Tingginya hasil belajar pada kelas yang menggunakan model TPS dikarenakan dalam prosesnya melibatkan dua orang dalam satu kelompok sehingga dalam berdiskusi lebih fokus. Kelas yang menggunakan model NHT memiliki anggota yang lebih banyak dalam kelompoknya. Keuntungan dalam kelompok NHT akan diperoleh banyak ide, akan tetapi jumlah anggota yang banyak menyebabkan hanya beberapa siswa yang bekerja, terutama bagi siswa yang aktif, sehingga siswa yang kurang aktif hanya diam dan menunggu hasil dari anggota yang aktif.

Selain uji perbedaan kedua model pembelajaran antara kelas eksperimen 1 dan 2, uji perbedaan antara kedua model pada kelas eksperimen 1 dan kelas eksperimen 2 juga dilakukan. Berdasarkan analisis uji perbedaan hasil belajar aspek kognitif antara yang menggunakan model NHT dan TPS pada kelas eksperimen 1 menggunakan rumus $t$-Test pada program Microsoft Excel 2007, diketahui harga $t_{\text {hitung }}=-5,87$ dengan derajat bebas 76 dan $\alpha=5 \%$ sehingga harga $t_{\text {tabel }}$ adalah 1,67 . Karena nilai $t_{\text {hitung }}$ negatif maka berlaku $\mathrm{H}_{0}$ ditolak apabila $t_{\text {hitung }}$ lebiih kecil dari $t_{\text {tabel }}$ ( $\mathrm{t}_{\text {hitung }}<\mathrm{t}$ tabel), sehingga dari hasil analisis Ho ditolak dan $\mathrm{Ha}$ diterima. Dengan demikian terbukti secara statistik bahwa terdapat perbedaan hasil belajar aspek kognitif antara perlakuan yang menggunakan model pembelajaran kooperatif tipe NHT dengan TPS. Hasil analisis uji hipotesis untuk kelas eksperimen 1 yang menggunakan model NHT dan TPS dapat dilihat pada Tabel. 
MIFTAHUL HASANAH, DKK.

Tabel 3

Hasil Uji Hipotesis Data Hasil Belajar menggunakan Model NHT dan TPS pada Kelas Eksperimen 1

\begin{tabular}{|l|l|l|}
\hline \multicolumn{1}{|c|}{ Statistik } & \multicolumn{1}{c|}{ Model NHT } & \multicolumn{1}{c|}{ Model TPS } \\
\hline Jumlah sampel & 39 & 40 \\
Rata-rata & 53,07 & 66,77 \\
Varians $\left(\mathrm{S}^{2}\right)$ & 117,17 & 95,41 \\
$\mathrm{t}_{\text {titung }}$ & $-5,87$ & $\mathrm{t}_{\text {hitung }}<\mathrm{t}_{\text {tabel }}$ \\
$\mathrm{t}_{\text {tabel }}$ & 1,67 & $\mathrm{H}_{0}$ ditolak, $\quad \mathrm{H}_{\mathrm{a}}$ \\
& & diterima \\
\hline
\end{tabular}

Berdasarkan analisis uji perbedaan hasil belajar aspek kognitif antara yang menggunakan model NHT dan TPS pada kelas eksperimen 2 menggunakan rumus $t$-Test pada program Microsoft Excel 2007, diketahui harga thitung $=-5,78$ dengan derajat bebas 78 dan $\alpha=5 \%$ sehingga harga $t_{\text {tabel }}$ adalah 1,67. Karena nilai thitung negatif maka berlaku $\mathrm{H}_{0}$ ditolak apabila thitung lebih kecil dari $t_{\text {tabel }}$ (thitung $<t_{\text {tabel}}$ ), sehingga dari hasil analisis Ho ditolak dan Ha diterima. Dengan demikian terbukti secara statistik bahwa terdapat perbedaan hasil belajar aspek kognitif antara perlakuan yang menggunakan model pembelajaran kooperatif tipe NHT dengan TPS. Hasil analisis uji hipotesis untuk kelas eksperimen 2 yang menggunakan model NHT dan TPS dapat dilihat pada Tabel 4.

Tabel 4

Hasil Uji Hipotesis Data Hasil Belajar menggunakan Model NHT dan TPS pada Kelas Eksperimen 2

\begin{tabular}{|l|l|l|}
\hline \multicolumn{1}{|c|}{ Statistik } & Model TPS & \multicolumn{1}{|c|}{ Model NHT } \\
\hline Jumlah sampel & 39 & 40 \\
Rata-rata & 44,20 & 56,48 \\
Varians $\left(\mathrm{S}^{2}\right)$ & 78,39 & 103,92 \\
$\mathrm{t}_{\text {hitung }}$ & $-5,75$ & $\mathrm{t}_{\text {hitung }}<\mathrm{t}_{\text {tabel }}$ \\
$\mathrm{t}_{\text {tabel }}$ & 1,67 & $\mathrm{H}_{0}$ ditolak, $\mathrm{H}_{\mathrm{a}}$ diterima \\
\hline
\end{tabular}




\section{PENUTUP}

\section{Kesimpulan}

Berdasarkan hasil penelitian dan pembahasan, maka kesimpulan yang diperoleh dalam penelitian ini adalah terdapat perbedaan hasil belajar IPA Biologi yang menggunakan model pembelajaran kooperatif tipe Nmbered Heads Together (NHT) dengan Think Pair Share (TPS) pada siswa kelas VIII materi pertumbuhan dan perkembangan pada makhluk hidup di SMPN 13 Mataram Tahun Ajaran 2015/2016.

\section{Saran}

Berdasarkan hasil penelitian, maka diajukan saran sebagai berikut (1) Perlu adanya perencanaan yang baik oleh guru untuk mempersiapkan pembelajaran sehingga dapat terlaksana sesuai dengan tujuan yang akan dicapai. (2) Para peneliti dapat melanjutkan penelitian dengan menggunakan model pembelajaran Numbered Heads Together (NHT) dan Think Pair Share (TPS) untuk pokok bahasan yang lain dan untuk mengukur hasil belajar aspek afektif dan psikomotorik.

\section{DAFTAR PUSTAKA}

Jufri, A. W. 2010. Belajar dan Pembelajaran Sains. Lombok Barat NTB: Arga Puji Press.

Rulam. 2014. Teori Belajar dan Pembelajaran. http://www.infodiknas.com/teori-belajar-danpembelajaran.html. Diakses tanggal 5 Desember 2015.

Solihin, A. 2014. Pengertian Belajar dan Macam-Macam Teori Belajar. $\quad$ http://visiunibversal.blogspot.co.id. Diakses tanggal 4 Desember 2015

Suprijono, A. 2012. Cooperative Learning Teori dan Aplikasi PAIKEM. Yogyakarta: Pustaka Belajar.

Sisdiknas. $2013 . \quad$ Kurikulum 2013. http://kemdikbud.go.id/kemdikbud/artikel-mendikbudkurikulum2013. Diakses tanggal 5 Desember 2015 
Permana, Y. 2011. Studi Komparasi Hasil Belajar Biologi Antara Pembelajaran Menggunakan Strategi Kooperatif Tipe Berpikir-Berpasangan-Berbagi dan Tipe Mencari Pasangan pada Peserta didik Kelas VIII SMP Negeri 22 Mataram Tahun Ajaran 2010/2011. Skripsi. Mataram: FKIP.

Sumiati dan Asra. 2007. Metode Pembelajaran. Bandung: CV Rencana Prima.

Muamar, M. R. dan Amelia, R. P. 2013. Perbandingan Hasil Belajar Peserta didik Melalui Model Kooperatif Tipe Think Pair Share (TPS) dengan Tipe Numbered Headss Together (NHT) pada Materi Hidrosfer di Kelas VII SMP Negeri 5 Peusangan. Jurnal Pendidikan Almuslim (Online). Vol. 1 No. 1: 39.

Muzalifah. 2011. Perbandingan Hasil Belajar Kimia Siswa Antara yang Menggunakan Model Kooperatif Tipe NHT dan TPS. Skripsi (Online). Jakarta: Fakultas Ilmu Tarbiyah dan Keguruan

Setiawan, D. A., Elfi S., Sri M. 2013. Prestasi Belajar dengan Pembelajaran Kooperatif Tipe Numbered Heads Together (NHT) Lebih Tinggi daripada Think Pair Share (TPS) pada Materi Pelajaran Tata Senyawa Kimia dan Persamaan Reaksi Kimia. Jurnal Pendidikan Kimia (JPK), Vol. 2 No. 4 Tahun 2013.

Murti, M. M. S., Tri R. dan Surya B. U. 2014. Studi Komparasi Metode Pembelajaran Kooperatif Numbered Heads Together (NHT) dan Thin Pair Share (TPS) dengan Memperhatikan Kemampuan Matematika terhadap Prestasi Belajar Siswa pada Materi Pokok Larutan Penyangga di SMA Negeri 1 Jumapolo Tahun Pelajaran 2013/2014. Jurnal Pendidikan Kimia (Online). Vol. 3 No. $4: 77$.

Setyaningsih, A., Sri R. D. A., Sulistyo S. 2015. Studi Komparasi Pembelajaran Kooperatif Tipe Numbered Heads Together (NHT) dan Think Pair Share (TPS) terhadap Prestasi Belajar pada Materi Koloid Ditinjau dari Kemampuan Memori Siswa Kelas XI SMA Negeri 3 Sukoharjo Tahun Pelajaran 2013/2014. Jurnal Pendidikan Kimia (JPK). Vol. 4 No. 1 Tahun 2015 Hal. 165-173.

224 BIOTA: Jurnal Tadris IPA Biologi FITK IAIN Mataram 
Rahmawati, I. 2010. Model Pembelajaran Kooperatif dengan Model Numbered Heads Together (NHT) dan Think Pair Share (TPS) Ditinjau dari Motivasi Berprestasi dan gaya Belajar Siswa. Tesis (Online). Surakarta: Universitas Sebelas Maret.

Aisyah, M. Masykuri, Sulistyo S. 2013. Pembelajaran Kimia Menggunakan Model Think Pair Share (TPS) dan Numbered Head Together Dilengkapi Handout Ditinjau dari Kemampuan Awal dan Kemampuan Tematik Tesis (Online) http://jurnal.fkip.uns.ac.id. Diakses tanggal 10 September 2015. 